\title{
Effect of Crop Establishment Methods and Weed Management Practices on Productivity and Profitability of Clusterbean under Semi-arid Region of Rajasthan
}

\author{
O.P. Meena1, Vipin Kumar ${ }^{1}$, S.K. Jain ${ }^{1}$, M.R. Yadav¹, B.R. Meena ${ }^{2}$, \\ Ravi Kumar Meena ${ }^{3}$, Saroj Kumari Yadav ${ }^{1}$
}

$10.18805 / L R-4737$

\begin{abstract}
Background: Adequate tillage checks and delays the emergence of weeds and provides a more favourable environment for early crop establishment. Slow growth of crop plant provides favourable environment for emergence of weeds. Cultural as well as mechanical practices such as hand weeding and intercultural are effective but unavailability of labour and continuous rainfall in rainy season does not permit for timely management of weeds Chemical weed control is effective weed management option which provides effective control of weeds. It is well known that weeds are ubiquitous but their presence in cropped area particularly in rainy season crops like clusterbean act as major limiting factor in achieving high potential yield. The current study aimed to study the impact of crop establishment methods and weed control practices on productivity and profitability of clusterbean.

Methods: A field experiment was carried out to find out suitable method of crop establishment methods and weed management practices in clusterbean during kharif seasons of 2018, 2019 and 2020. The experiment was conducted in spilt plot design with three replications. The treatments were four crop establishment methods viz., conventional sowing, zero tillage sowing, broad bed sowing, zero tillage sowing with mulch as main plots and four weed control practices viz., weedy check, pendimethalin+imazethapyr $1000 \mathrm{~g}$ $\mathrm{ha}^{-1}, \mathrm{~T}_{3}$ - Imazethapyr $40 \mathrm{~g} \mathrm{ha}^{-1}, \mathrm{~T}_{4}$-Imazethapyr+imazamox $40 \mathrm{~g} \mathrm{ha}^{-1}$ as sub plot treatments

Result: The broad bed sowing of clusterbean along with pre-emergence application of pendimethalin+ imazethapyr $1000 \mathrm{~g}$ ha-1 was found effective to achieve higher productivity and farm profitability.

Key words: Clusterbean, Crop establishment, Productivity, Profitability, Weed management, Weed.
\end{abstract}

\section{INTRODUCTION}

Clusterbean (Cyamopsis tetragonoloba L.) is one of the important drought hardy and deep rooted and adapted to the harsh climatic conditions of arid and semi arid zone of India. In India cluster bean mainly grown during kharif season. India accounts for more than three-fourth (about $80 \%$ ) of the global production of cluster bean. The area under the crop is reported about 53.45 ha with production is about 32.86 tones and productivity is $615 \mathrm{~kg}$ per ha during the year 2018-19. (Anonymous, 2019 a) Rajasthan is the largest cluster been producing state in India followed by Haryana, Gujarat, UP, MP and Punjab. Rajasthan has an area of 46.30 lakh ha, production of $27.47 \mathrm{M}$ tonnes and with a productivity of $593 \mathrm{~kg}$ per ha during the agricultural year 2014-15.The state contributes about 85 per cent of the total area under crop in the country (Anonymous, 2019 b).

The clusterbean is a slow growing warm legume kharif season crop and weeds are serious problem due to favourable conditions for their growth. Adequate tillage checks and delays the emergence of weeds and provides a more favourable environment for early crop establishment. Slow growth of crops plant provides a more favourable environment for emergence of weeds. Cultural as well as mechanical practices such as hand weeding and intercultural are effective but unavailability of labour and continuous rainfall in rainy season does not permit to remove weeds
${ }^{1}$ Rajasthan Agricultural Research Institute, SKN Agricultural University, Durgapura-302 018, Jaipur, Rajasthan, India.

${ }^{2}$ SKN College of Agriculture, SKN Agriculture University, Jobner303 329, Jaipur, Rajasthan, India.

${ }^{3}$ College of Agriculture, SKN Agriculture University, Dholpur328001 , Rajasthan, India.

Corresponding Author: O.P. Meena, Division of Agronomy, Rajasthan Agricultural Research Institute, SKN Agricultural University, Jobner, Durgapura-302 018, Jaipur, Rajasthan, India. Email: opmeena.agro@sknau.ac.in

How to cite this article: Meena, O.P., Kumar, V., Jain, S.K., Yadav, M.R., Meena, B.R., Kumar, R.K. and Yadav, S.K. (2022). Effect of Crop Establishment Methods and Weed Management Practices on Productivity and Profitability of Clusterbean under Semi-arid Region of Rajasthan. Legume Research. DOI: 10.18805/LR-4737. Submitted: 16-07-2021 Accepted: 29-11-2021 Online: 24-01-2022

timely. Chemical weed control is effective option which is cheaper and provides effective control of weeds. Amongst agronomic factors known to augment crop production appropriate weed management is considered to be important. Poor weed management is one of the important factor for low yield of this crop. Slow growth at initial stages of the crop favors recurrent flushes of weeds, which compete with crop for essentials of growth and cause heavy reduction 
in its seed yield. Critical period for crop-weed competition in cluster bean has been identified as 20 to 30 days after sowing and presence of weeds showed in yield reductions by 47 to $92 \%$ Punia et al., (2011). Among different weed management practices, use of herbicides is the only choice under adverse situations.

Therefore, the present study was planned to asses the effect of crop establishment method and different weed control practice for enhancing crop productivity and farm profitability of clusterbean.

\section{MATERIALS AND METHODS}

A field experiment was conducted at Agricultural Research Farm, Rajasthan Agricultural Research Institute, Durgapura, Jaipur $\left(26^{\circ} 51^{\prime} \mathrm{N}, 75^{\circ} 47^{\prime} \mathrm{E}\right.$ at an altitude of $390 \mathrm{~m}$ above mean sea level). The experiment was conducted during 2018 to 2020 on the same site and layout. The experimental site was characterized by cold winters and hot summers. Occurrence of frost (below $0^{\circ} \mathrm{C}$ ) during December/January and hot desiccating winds $\left(450^{\circ} \mathrm{C}\right)$ in May-June are quite common. The average annual rainfall of zone was $563 \mathrm{~mm}$ of which about $90 \%$ is received during later half of June to September with erratic distribution over time and apace. The soil of the experimental site was loamy sand in texture with slightly alkaline in reaction $(\mathrm{pH} 8.1)$. The experimental soil was low in organic carbon $\left(2.1 \mathrm{~g} \mathrm{~kg}^{-1}\right)$, high in phosphorus (34 kg ha-1), medium in potassium $\left(191 \mathrm{~kg} \mathrm{ha}^{-1}\right)$ and sulphur $\left(7.8 \mathrm{mg} \mathrm{kg}^{-1}\right)$. The experiment was conducted in spilt plot design with three replications. The treatments consisted of sixteen treatment combinations, main plots crop establishment methods viz. Conventional sowing, Zero tillage sowing, broad bed sowing, zero tillage sowing with mulch and four weed control practices are weedy check, Pendimethalin + imazethapyr $1000 \mathrm{~g} \mathrm{ha}^{-1}$ pre-emergence, Imazethapyr $40 \mathrm{~g} \mathrm{ha}^{-1}$ post-emergence Imazethapyr + imazamox $40 \mathrm{~g} \mathrm{ha}^{-1}$ post-emergence the experiment was conducted in spilt plot design with three replications. Guar variety 'RGC 1038' was sown at $30 \mathrm{~cm} \times 10 \mathrm{~cm}$ spacing using seed rate $20 \mathrm{~kg}$ ha-by seed cum fertilizer drill and by bed planter on raised beds with four rows of clusterbean on the bed (90 cm wide). The crop was fertilized with uniform dose of $20 \mathrm{~kg} \mathrm{~N}$ and $40 \mathrm{~kg} \mathrm{P}_{2} \mathrm{O}_{5}$ ha $^{-1}$ through urea and DAP, respectively. Herbicides were applied as per treatments. By knapsack sprayer fitted with a T- jet nozzle using a spray volume of 800 It.ha $^{-1}$ weedy check plots remain infested with native population of weeds till harvest.

Data on weed density were recorded from an area enclosed in the quadrate of $0.5 \mathrm{~m}^{2}$ randomly selected at two places in each plot. Weeds collected from $0.5 \mathrm{~m}^{2}$ area at two places were first sun dried for 2-3 days and then oven dried at $70^{\circ} \mathrm{C}$ till the constant weight was recorded. The weed dry matter obtained at 60 DAS was expressed in gram per square meter $\left(\mathrm{g} / \mathrm{m}^{2}\right)$. The data on weed density and weed dry weight thus obtained were subjected to square root transformation $(\sqrt{ } x+0.5)$ as wide variations existed among the treatments before statistical analysis.
The weed control efficiency (WCE) and weed index were calculated by using the following formula: The formula given by Mishra and Mishra (1997).

$$
\text { Weed control efficiency }(\text { WCE })=\frac{X-Y}{X} \times 100
$$

Where,

$X=$ Weed dry matter in weedy check $(\mathrm{g})$.

$\mathrm{Y}=$ Weed dry matter in respective treatment $(\mathrm{g})$.

Weed index is the per cent reduction in crop yield under a particular treatment due to the presence of weeds in comparison to weed free plot as suggested by Gill and Kumar (1969). This is used to assess the efficacy of a herbicide. Lesser the weed index, better is the efficiency of a herbicide. It is expressed in percentage and was determined with the help of following formula:

$$
\text { Weed index }(\%)=\frac{X-Y}{X} \times 100
$$

Where,

$W I=$ Weed index; $X=$ Crop yield from weed free plot and $\mathrm{Y}=$ Crop yield from the treated plot for which weed index is to be worked out.

The crop was harvested at physiological maturity when plants turned golden yellow. The net returns were computed by deducting the total cost of cultivation from the gross returns and Benefit: Cost ratio was calculated by dividing the net returns with the cost of cultivation. The data obtained on various parameters - weed count, weed density, yield attributes and yield, nutrient uptake by crop and nutrient removal by weeds were tabulated and subjected to analysis of variance techniques as described by Gomez and Gomez (1984).

\section{RESULTS AND DISCUSSION}

\section{Crop establishment methods and weed management practices on weed dynamics}

The crop was mainly infested narrow leaved weeds and broad leaved weeds viz Cyanadon dactylon, Echinochloa colona, Brachiaria ramose, Amarathus viridis, Digeraar vensis, Commelina benghalensis and Trianthema portulacustrum etc. Pooled experimental results revealed that broad bed sowing method had significant reduce weed density over conventional method of sowing, zero tillage sowing and zero tillage sowing with mulch. The per cent of decrease in weed density in broad bed sowing method was 51 to $42 \%$ as compared to conventional method of sowing, 44 to $35 \%$ as compared to zero tillage sowing method and 40 to $25 \%$ as compared to zero tillage sowing method with mulch at different stage of crop (Table 1). This might have happened due to more foliage growth of bed sowing clusterbean which caused hindrance in germination of weeds and deeper burial of weed seeds during formation of raised beds. In the long run, pre-mixture of pendimethalin + imazethapyr @800 g ha-1 pre-emergence was found more effective for controlling monocot weeds as well as dicot 
weeds. This might be due to the broad spectrum control of weeds because of combination of two herbicides with different mode of action and decreasing residual effect of pendimethalin and prolonged residual effect of imazethapyr. The result conformity was found with Soltani et al., (2012) Jha and Soni (2013). The weed dry weight of monocot and dicot weeds in conventional sowing plot were significantly higher than bed and Zero tillage sowing with mulch.

\section{Effect of weed management practices}

All the weed management practices significantly reduce weed density over weedy check and the highest weed density was noticed in weedy check. The application of pendimethalin + imazethapyr $1000 \mathrm{~g} \mathrm{ha}^{-1}$ significantly reduce weed density over weed check plot which was statistically at par with Imazethapyr+imazamox $40 \mathrm{~g} \mathrm{ha}^{-1}$ and Imazethapyr $40 \mathrm{~g} \mathrm{ha}^{-1}$ at different stage of crop (Table 1). The percent of decrease in weed density over weedy check due to application of Pendimethalin + imazethapyr $1000 \mathrm{~g} \mathrm{ha}^{-1}$ was 79 to $82 \%$ at different stage of crop. This might have happened due to the fact that imazethapyr inhibits the plastid aceto-lactate synthesis (ALS) in plants. The ALS inhibitors stop cell division and reduces carbohydrate translocation in susceptible plants (Gupta, 2008) Imazethapyr by virtue of wide spectrum weed control (both grassy and broad-leaved weeds) without causing any phytotoxicity to crop plants emerged as economically viable option of post-emergence application . Similar results are reported by Patil et al., (2013) and Sharma et al., (2017) in clusterbean crop.

Effect of crop establishment method and weed management practices on weed dry weight and weed index

\section{Effect of sowing method}

Three years pooled data presented in Table 1 insinuates that, weed dry weight and weed index were significantly influced by different sowing method. The significantly lowest dry weights of weed was observed in broad bed sowing method followed by zero tillage with mulch and zero tillage while highest weed dry weight observed in conventional sowing method. The per cent of decrease in weed dry weight in broad bed sowing method was 54 to $71 \%$ as compared to conventional method of sowing, 27 to $34 \%$ as compared to zero tillage sowing method with mulch on pooled basis. Significantly lower dry weight of weeds (Table 1) was observed in broad bed planting method that may be due to better crop growth in bed planting which did not allow weeds to get optimum sunlight, moisture and nutrient supply for accumulation of more dry matter in them and thus checked their growth. Similar were the findings of Jha and Soni (2013) in soyabean and Kumar et al., (2006) in blackgram where broad bed planting resulted in minimum total weed count and dry matter.

\section{Effect of weed management practices}

Different weed management practices significantly reduced the dry weight of both narrow-leaved and broadleaved weeds over weedy check. On pooled basis, pendimethalin+

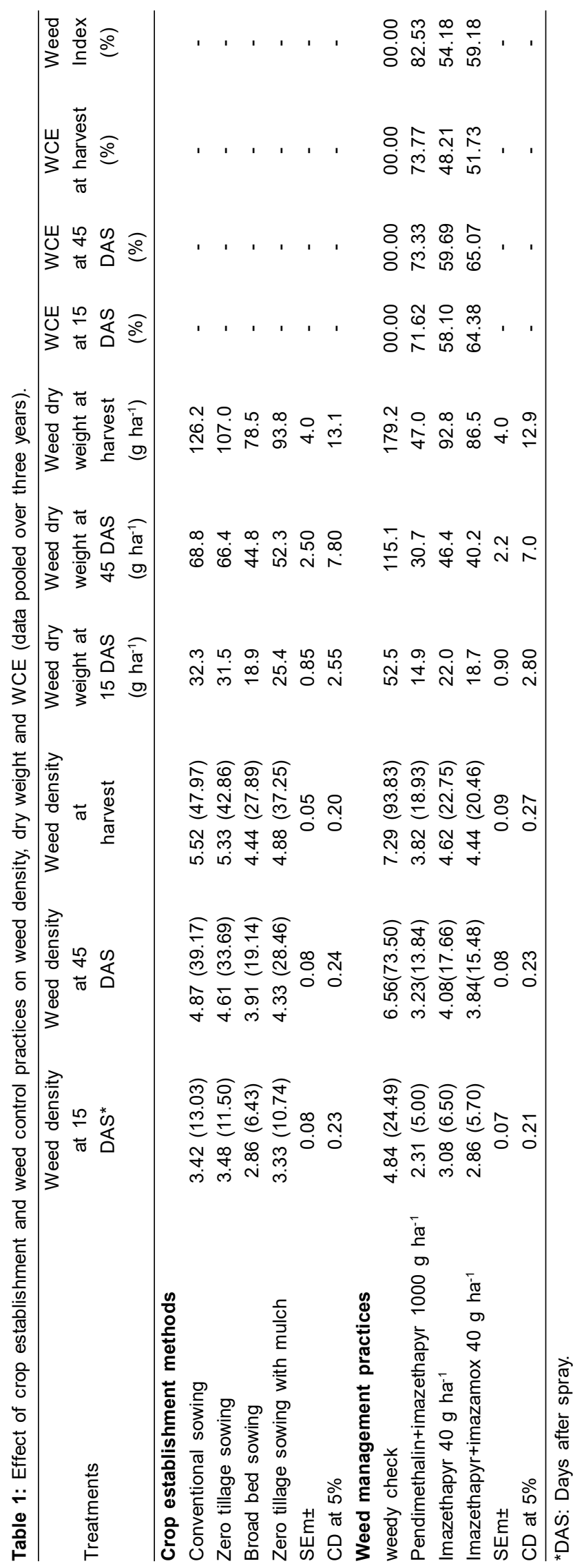


imazethapyr $1000 \mathrm{~g} \mathrm{ha}^{-1}$ recorded maximum reduction in total weed dry weight and maximum weed index as compared to weedy check but remained statistically at par with Imazethapyr + imazamox $40 \mathrm{~g} \mathrm{ha}^{-1}$ and Imazethapyr $40 \mathrm{~g} \mathrm{ha}^{-1}$ treatment. The percent of decrease in weed dry weight over weedy check due to application of Pendimethalin + imazethapyr $1000 \mathrm{~g} \mathrm{ha}^{-1}$ was 72 to $84 \%$, due to Imazethapyr + imazamox $40 \mathrm{~g} \mathrm{ha}^{-1}$ was, 65 to $51 \%$ and due to Imazethapyr $40 \mathrm{~g} \mathrm{ha}^{-1}$ was 60 to $48 \%$ on pooled basis. Weed index point of view highest weed index was recorded under Pendimethalin + imazethapyr $1000 \mathrm{~g} \mathrm{ha}^{-1}(82.53 \%)$ and lowest weed index was recorded with Imazethapyr 40 $\mathrm{g} \mathrm{ha}^{-1}(54.18 \%)$. Long lasting effects in reducing weed dry weight might be due to weed seed damage caused by preemergence application of Pendimethalin + imazethapyr 1000 $\mathrm{g} \mathrm{ha}^{-1}$ and suppression of established plants of both narrow and broad leaved weeds by imazethapyr and its greater efficiency to retard cell division of meristems as a result of which weeds died very rapidly. Fayaz et al., (2017) also reported similar results of effective control in weed population and weed dry matter in mungbean. The effective control of weeds by early post-emergence application of imazethapyr + imazamox (ready mix) which was found effective against all kind of weeds especially broad-leaved weeds and resulted in significant reduction in the dry weight of weeds. Similar results are reported by Gupta et al., (2015) and Sharma et al., (2017) in clusterbean crop. All those weeds were suppressed by the application of post emergence herbicide or imposed with hand weeding. These results corroborate the findings of Gupta et al., (2015), Sharma et al., (2017) and Yadav and Mundra (2017) in clusterbean.

Crop establishment methods and weed management practices on yield attributes and yield of clusterbean

On pooled data basis the highest number of pods per plant, pod length and number of seeds per pod were found under broad bed sowing and application of pendimethalin+ imazethapyr $1000 \mathrm{~g} \mathrm{ha}^{-1}$ as pre emergence herbicides. Significantly higher grain yield of cluster bean (980 kg ha-1) was obtained with adoption of broad bed sowing compared to conventional sowing (849 $\mathrm{kg} \mathrm{ha}^{-1}$ ), zero tillage sowing with mulch (803 $\mathrm{kg} \mathrm{ha}^{-1}$ ) and zero tillage sowing (712 kg ha-1). Significantly higher straw yield was recorded in broad bed furrow sowing as compared to conventional sowing, Broad bed provided the loose soil mass with adequate soil moisture, better growing condition and lesser competition by weeds which result in increase in yield. This might be due to the fact that under favourable soil conditions, the plant accumulates and translocates the photosynthates from source to sink more efficiently which in turn increased yield attributes and yield. Similar results of higher grain yield and straw yield were also reported earlier by Pandey et al., (2018) in blackgram, Garud et al., (2019) in pigeonpea and Halli and Angadi (2019) in cowpea also reported higher grain yield with broad bed method of sowing.

All weed management practices had significant effect on yield of clusterbean as compared to weedy check.
Application of pendimethalin + imazethapyr $1000 \mathrm{~g} \mathrm{ha}^{-1}$ as pre emergence recorded significantly higher yields (seed and straw yield) as compared to weedy check which was statistically at par with Imazethapyr + imazamox $40 \mathrm{~g} \mathrm{ha}^{-1}$ post emergence and Imazethapyr $40 \mathrm{~g} \mathrm{ha}^{-1}$ post emergence during the years of experimentation. On pooled basis (Table 2), there were $82 \%$ improvement in seed yield and $745 \%$ improving in straw yield with the application of pendimethalin + imazethapyr $1000 \mathrm{~g} \mathrm{ha}^{-1}$, Imazethapyr + imazamox $40 \mathrm{~g}$ ha $^{-1}$ post emergence were $59 \%$ higher in seed yield and $34 \%$ higher in straw yield in case application of imazethapyr $40 \mathrm{~g}$ ha $^{-1}$ post emergence were $54 \%$ have higher seed yield and $52 \%$ in straw yield over the weedy check, respectively. The huge losses in yield was observed in weedy check plots due to heavy flushes of weeds during entire crop growth period and thereby caused severe more crop weed competition throughout the crop growth period for nutrients as well as moisture and thus, resulted in higher yield losses. Increase in seed yield might be due to the direct influence of various weed management treatments on the suppression of weeds. Higher grain yield in chemical weed management practices may be attributed due to effective and timely weed management under these treatments reduced the density as well as dry weight of weeds which facilitated the crop plants to have sufficient space, light, nutrient and moisture and thus the number of pods plant ${ }^{-1}$, test weight and finally the yield were increased. Similar results of more grain yield (Fayaz et al., 2017) are also observed in mungbean and Lhungdim et al., (2014). These results corroborate the findings of Sharma et al., (2017) and Singh and Godara (2015) in cluster bean crop.

\section{Crop establishment methods and weed management practices on economics of clusterbean}

Three years pooled data shows that (Table 2) the maximum gross returns (₹34729 ha-1) and net returns (₹20229 ha $\mathrm{h}^{-1}$ ) with B: C ratio (2.40) were observed with adoption of broad bed sowing method. Pandey et al., (2018) also reported higher $\mathrm{B}: \mathrm{C}$ ratio of 1.82 in blackgram with broad bed method. Naresh et al., (2015) also found that zero tillage reduced the impact of solar radiation by acting as a physical barrier resulting in lower soil temperature than the plough soil. Mulched soils retained 20 to $50 \%$ more water than unmulched soils Blanco-Canqui et al., (2007).

Among the various weed management practices, application of herbicides recorded higher gross return, net returns and $B: C$ ratio over the weedy check. Three years pooled data shows that (Table 2) application of pendimethalin + imazethapyr $1000 \mathrm{~g} \mathrm{ha}^{-1}$ recorded significantly higher gross returns (₹36456 ha-1) and net returns (₹22958 ha-1) and B: C ratio (2.70) over weedy check, imazethapyr + imazamox $40 \mathrm{~g} \mathrm{ha}^{-1}$ and imazethapyr @ $40 \mathrm{~g}$ ha $^{-1}$. The weedy check treatment had monetary returns and $\mathrm{B}: \mathrm{C}$ ratio ( $₹ 7277$ and 1.57 ) due to the heavy weed infestation in the weedy check treatment which was drastically reduce the seed yield of the clusterbean. The results were in 
Table 2: Effect of crop establishment and weed control practices on pooled yield attributes, yield and economics (data pooled over three years).

\begin{tabular}{|c|c|c|c|c|c|c|c|c|}
\hline Treatments & $\begin{array}{l}\text { No. of } \\
\text { pods } \\
\text { plant }^{-1}\end{array}$ & $\begin{array}{l}\text { Pod } \\
\text { length } \\
\mathrm{cm}\end{array}$ & $\begin{array}{l}\text { No. of } \\
\text { seeds } \\
\text { pod }^{-1}\end{array}$ & $\begin{array}{l}\text { Seed } \\
\text { yield } \\
\mathrm{kg} \mathrm{ha}^{-1}\end{array}$ & $\begin{array}{c}\text { Straw } \\
\text { yield } \\
\text { kg ha-1 }\end{array}$ & $\begin{array}{c}\text { GR } \\
₹ \\
\text { ha }^{-1}\end{array}$ & $\begin{array}{c}\text { NR } \\
₹ \\
\text { ha }^{-1}\end{array}$ & $\begin{array}{l}\mathrm{B}: \mathrm{C} \\
\text { ratio }\end{array}$ \\
\hline \multicolumn{9}{|l|}{ Crop establishment methods } \\
\hline Conventional sowing & 27.57 & 5.57 & 6.24 & 849 & 1971 & 30125 & 15875 & 2.11 \\
\hline Zero tillage sowing & 29.43 & 5.66 & 6.11 & 712 & 1904 & 25640 & 13140 & 2.05 \\
\hline Broad bed sowing & 34.89 & 6.42 & 6.98 & 980 & 2246 & 34729 & 20229 & 2.40 \\
\hline Zero tillage sowing with mulch & 30.78 & 5.90 & 6.62 & 803 & 1988 & 28678 & 15028 & 2.10 \\
\hline SEm \pm & 0.56 & 0.104 & 0.068 & 25 & 52 & - & - & - \\
\hline$C D$ at $5 \%$ & 1.99 & 0.366 & 0.239 & 76 & 160 & - & - & - \\
\hline \multicolumn{9}{|l|}{ Weed control practices } \\
\hline weedy check & 23.24 & 5.10 & 4.81 & 561 & 1403 & 20057 & 7277 & 1.57 \\
\hline Pendimethalin + imazethapyr $1000 \mathrm{~g} \mathrm{ha}^{-1}$ & 35.96 & 6.71 & 7.77 & 1024 & 2460 & 36458 & 22958 & 2.70 \\
\hline Imazethapyr $40 \mathrm{~g} \mathrm{ha}^{-1}$ & 31.48 & 5.74 & 6.58 & 865 & 2134 & 30881 & 17481 & 2.30 \\
\hline Imazethapyr + imazamox $40 \mathrm{~g} \mathrm{ha}^{-1}$ & 32.00 & 6.00 & 6.78 & 893 & 2144 & 31792 & 18342 & 2.36 \\
\hline SEm \pm & 0.53 & 0.132 & 0.226 & 22 & 60 & - & - & - \\
\hline $\mathrm{CD}$ at $5 \%$ & 1.58 & 0.388 & 0.663 & 65 & 185 & - & - & - \\
\hline
\end{tabular}

conformity with the findings of Poornima et al., (2018) and Tamang et al., (2015).

\section{CONCLUSION}

The results of the experiment revealed that broad bed sowing method in clusterbean the seed yield (980 kg ha-1), straw yield (2246 kg ha-1) and B:C ratio (2.40). This was statistically significantly superior over other methods of sowing. Secondly weed control practices in clusterbean highest seed yield $\left(1024 \mathrm{~kg} \mathrm{ha}^{-1}\right)$, straw yield $\left(2460 \mathrm{~kg} \mathrm{ha}^{-1}\right)$ and $\mathrm{B}: \mathrm{C}$ ratio 2.70 with pendimethalin+imazethapyr $1000 \mathrm{~g} \mathrm{ha}^{-1}$ which was statistically superior over weedy chick, imazethapyr + imazamox $40 \mathrm{~g} \mathrm{ha}^{-1}$ and imazethapyr $40 \mathrm{~g} \mathrm{ha}^{-1}$ treatments of weed control practices.

\section{REFERENCES}

Anonymous, (2019a). Agricultural Statistics at a Glance, Ministry of Agriculture and Farmers Welfare, New Dehli, India.

Anonymous, (2019b). Agricultural Statistics at a Glance, Directorate of Agriculture, Jaipur, Rajasthan.

Blanco-canqui, H., Lal R., Post, W.M., Izaurralde, R.C. and Shipitalo, M.J. (2007). Soil hydraulic properties influenced by corn stover removal from no-till corn in Ohio. Soil and Tillage Research. 92: 144-155.

Fayaz, A.B., Dar, S.A., Ajaz, A. Lone., Ansarl Huq., Alie, B.A., Dar, Z.A., Bhat M.A. and Gul Zaffar. (2017). Effect of land configuration and weed management on mungbean productivity under temperate conditions of Kashmir, India. International Journal of Current Microbiology and Applied Science. 6 (10): 863-870.

Garud, H.S., Asewar, B.V., Dhawan, A.S., Gokhale, D.N. and Mirzal, A.B., (2019). Productivity and soil moisture conservation studies of pigeon pea based intercropping systems as influenced by different land configurations. Legume Research-An International Journal. 42(3): 365-369.
Gill, G.S., Kumar, V. (1969). Weed index, a new method for reporting weed control trials. Indian Journal of Agronomy. 142: 96-98.

Gomez, K.A. and Gomez, A.A. (1984). Statistical Procedures for Agricultural Research. John Wiley and Sons.

Gupta, O.P., Functional Features of Some Currently Used Herbicides (2008). Modern Weed Management $3^{\text {rd }}$ Revised Edition, AGROBIOS (INDIA)., Jodhpur, 223.

Gupta, V., Singh S.P., Yadav, R.S. (2015). Yield performance and nutrient uptake as influenced by integrated weed management in clusterbean. Indian Journal of Weed Science. 47(1): 82-84.

Halli, H.M. and Angadi, S.S. (2019).Influence of land configuration on rain water use efficiency yield and economics of cowpea (Vigna unguiculata L.) in maize cowpea sequence cropping under rainfed condition of Northern Transitional Zone. Legume Research-An International Journal. (42): 211-215.

Jha, A.K. and Soni, M. (2013). Weed management by sowing methods and herbicides in soybean. Indian Journal of Weed Science. 45(4): 250-252.

Kumar, S., Angiras, N.N and Singh, R. (2006). Effect of planting and weed control methods on weed growth and seed yield of blackgram. Indian Journal of Weed Science. 38 (2): 73-76

Lhungdim, J., Singh Y., Singh O.N. and Chongtham, S.K. (2014). Efficiency of different weed control methods on yield and economics of rainfed lentil (Lens culinaris). Journal of Food Legumes. 27(1): 32-36.

Mishra, M. and Misra, A. (1997). Estimation of integrated pest management index in jute-A new approach. Indian Journal of Weed Science. 29(1): 39-42.

Naresh, R.K., Singh S.P., Singh A., Kumar D., Tomar S.S., Dhaliwal S.S., Nawaz A., Kumar N. and Gupta, R.K. (2015). Effects of tillage and residue management on soil aggregation, soil carbon sequestration and yield in rice-wheat cropping system. International Journal of Current Microbiology and Applied Science. 6 (2): 1591-1609. 
Pandey, D., Tomar S.S., Singh A., Pandey A.K. and Kumar, M. (2018). Effect of land configuration and nutrient management regimes on performance and productivity of blackgram (Vigna mungo L.). Annals of Plant and Soil Research. 20 (2): 125-129.

Patil, B.T., Bhalekar M.N., Shinde, K.G. (2013). Weed management in clusterbean (Cyamopsis tetragonoloba L.). National Symposium on Abiotic and Biotic stress management in vegetable crops.

Poornima, S., Lakshmi, Y., Shiva Prakash, Ram, T. and Srinivas, A. (2018). Weed management through early post-emergence herbicides to improve productivity and nutrient uptake in greengram. Indian Journal of Weed Science. 50 (1):82-84.

Punia, S.S., Singh, S., Yadav, D., (2011). Bioefficacy of Imzethapyar and Chlorimuron-ethyl in Cluster bean and their residual effect on succeeding rabi crops. Indian Journal of Weed Science. 43(1and2): 48-53.
Sharma, K., Rawat, G.S., Gaur, D., Sharma, A. (2017). Effect of post-emergence herbicides on weed control, growth and yield of clusterbean [Cyamopsis tetragonoloba (L.) Taub] in M.P. Agricultural Science Digest. 37(3): 179-184.

Singh, R., Godara, A.S. (2015). Weed control efficiency of postemergence herbicides and their effect on productivity of clusterbean [Cyamopsis tetragonoloba (L.) Taub]. Legume Research. 38(3): 415-418.

Soltani, N., Robert E., Peter, H. (2012). Weed control in dry bean with pendimethalin plus reduced rates of imazethapyr. International Research Journal of Agricultural Science and Soil Science. 2(8): 312-317.

Tamang, D., Nath, R. and Sengupta, K. (2015). Effect of herbicide application on weed management in green gram [Vigna radiata (L.)]. Advances in Crop Science and Technology. 3(2): 161-163.

Yadav, R.K., Mundra S.L., (2017). Weed management and sulphur nutrition in clusterbean for higher productivity and profitability. Journal of Pharmacognosy and Phytochemistry. 6(3): 06-08. 